Buana Sains Vol 17 No 1: 9 - 18, 2017

\title{
PROFIL PRODUKSI DAN PETERNAK KEMITRAAN BROILER DI WILAYAH GERBANG KERTOSUSILA
}

\author{
Nonok Supartini, Hariadi Darmawan dan Karunia Setyowati
}

Fakultas Pertanian Universitas Tribhuwana Tunggadewi, Malang

\begin{abstract}
The aim of this study are : (1) to identify production profile of broiler's partnership at Gerbangkertosusila region; (2) to identify farmer's profile of broiler's partnership at Gerbangkertosusila region; (3) to identify human resources development factors of broiler's partnership. This research done at Gerbangkertosusila region (Gresik, Bangkalan, Mojokerto, Surabaya, Sidoarjo dan Lamongan) East Java Province for 2 (two) months. This research is quantitative research with Cross Sectional Survey which mean questionnaire method by question list used in order to data collected as primary and secondary data. Primary data collected by survey, observation and depth interviewed with questionnaire used in order to got valid data, such as farmer profile and production profile information. Secondary data collected by data study and documentation from government documents and broiler's partnership corporation related documents. Data analysist was descriptive analysist. The conclusion of this study are : (1) Broiler's farmer profile are mostly $(90 \%)$ at productive ages with Senior High School graduated as the most common $(75 \%)$ and an enterpreneur as main profession $(45 \%)$ which more than 3 years of production periods $(80 \%)$ and had experiences at 2 kind of broiler's partnership models (60\%); (2) Management contract as the most choosen broiler's partnership models by respondents.
\end{abstract}

Keywords: Profile, Broiler's Partnership, GERBANG KERTOSUSILA

\section{Pendahuluan}

Budidaya ayam ras di Indonesia diklasifikasikan menjadi 2, yaitu budidaya broiler, untuk produksi daging, dan budidaya layer, untuk produksi telur. Sejarah broiler mencatat bahwa perkembangan broiler di Indonesia dimulai tahun 1970-an dan tersebar luas pada tahun 1980-an. Periode awal pengembangan broiler tersebut menjadi dasar industrialisasi agribisnis broiler dengan segala pasang surutnya sampai dengan periode sekarang.

Kondisi tersebut tidak berlangsung lama, pada periode awal tahun 2000-an kondisi tersebut berangsur pulih, karena didorong oleh faktor jumlah penduduk yang besar, konsumsi broiler yang masih rendah dan dugaan pertumbuhan ekonomi nasional yang positif. Upaya tersebut di-respon dengan peningkatan pemanfaatan bahan lokal pada industri pakan dan pembibitan broiler. Selain itu, jaringan pasar produksi dan konsumsi dibangun secara terpadu melalui pengembangan pola kemitraan inti plasma dengan peternak dan pengolahan hasil panen broiler sebagai bahan pangan sebagai perpanjangan tangan sampai ke tangan konsumen langsung. Upaya tersebut tercatat mampu mengangkat kembali gairah agribisnis broiler.

Wilayah Jawa Timur dikenal sebagai sentra industri pakan ternak dan mempunyai potensi peternakan yang 
cukup besar. Hal ini menjadi daya tarik pengembangan kemitraan broiler di Jawa Timur, namun data perkembangannya belum teridentifikasi, khususnya pada sisi pengembangan Sumber Daya Manusia (SDM) dalam hal ini adalah peternak. Penting kiranya adanya data base sebagai dasar evaluasi dan pengembangan kemitraan broiler nantinya. Peternakan broiler di Jawa Timur dengan sentra produksi tersebar di wilayah Gerbang Kertosusila (Gresik, Bangkalan, Mojokerto, Surabaya, Sidoarjo dan Lamongan) yang memiliki produksi broiler sebesar 84.219 ton/tahun $(57,74 \%)$ dari 159.671 ton/tahun produksi total broiler di Jawa Timur menjadikan wilayah ini sebagai wilayah potensial pengembangan broiler.

\section{Metode Penelitian}

Penelitian dilakukan di Wilayah gerbang kertosusila (Gresik, Bangkalan, Mojokerto, Surabaya, Sidoarjo dan Lamongan) Propinsi Jawa Timur, selama 2 (dua) bulan (April - Juni 2014).

Penelitian ini merupakan penelitian kuantitatif dengan rancangan penelitian survei yang menggunakan desain Cross Sectional Survey, yaitu :

1) Berdasarkan data yang dianalisis dalam penelitian ini, penelitian ini dapat dikategorikan dalam jenis penelitian observasional, dimana peneliti berupaya untuk melakukan observasi terhadap fenomena yang ada tanpa melakukan intervensi dan manipulasi atas fenomena yang diamati sebagai salah satu bentuk realitas objektif dan menjadi dasar objektifikasi peneliti.

2) Berdasarkan model analisa data, pene-litian ini dikategorikan dalam penelitian analitis, untuk menganalisis unit data yang muncul dari fenomena, dalam hal ini pengambilan sampel untuk di generalisasi dalam populasi.

Variabel penelitian ini yang dikaji adalah IP, FCR, umur peternak, tingkat pendidikan peternak, klasifikasi pekerjaan utama dan pengalaman beternak yang melatarbelakangi dalam melakukan kegiatan kemitraan dikaitkan dengan alternatif model kemitraan yang ditawarkan.

Metode pengambilan sampel dilakukan dengan teknik purpossive random sampling, yang diawali dengan studi data dari masing-masing pelaku kemitraan yang terdiri dari inti dan plasma. Secara purpossive, Inti terpilih menjadi responden, sedangkan sampling plasma dilakukan bagi plasma yang memiliki populasi jumlahnya lebih dari 5.000 ekor, dengan ketentuan/persyaratan plasma tersebut pernah melakukan kemitraan $\geq$ dua model kemitraan. Penentuan jumlah sampel minimal dilakukan dengan pertimbangan bahwa secara representatif sampel dapat mewakili populasi. Untuk menentukan jumlah sampel digunakan pendekatan rumus penetapan jumlah sampel sebagai berikut.

$$
n=\frac{N}{N(d)^{2}+1}
$$

\footnotetext{
Keterangan:

$\mathrm{n}=$ Jumlah sampel yang diinginkan

$\mathrm{N}=$ Jumlah Populasi.

$\mathrm{d}=$ Presisi yang ditetapkan 10\% yang merupakan tingkat penyimpangan dari karakteristik sampel terhadap populasi.
} 
Diperoleh sejumlah 809 steakholder kemitraan broiler yang memenuhi syarat populasi lebih dari 5.000 ekor dan pernah melakukan kemitraan $\geq$ dua model kemitraan dan diperoleh sampling sebanyak 750 responden.

Metode pelaksanaan survey dilakukan dengan Focussed Group Discussion (FGD). FGD dilakukan dengan perwakilan dari masing-masing model kemitraan yang memiliki kompetensi dan kepedulian terhadap pengembangan model kemitraan, berjumlah 4 orang/perwakilan inti dan 10 orang/perwakilan dari plasma. Peserta FGD sudah mulai diseleksi bersamaan dengan pemberian kuisioner yang sesuai dengan kriteria penelitian.

Data penelitian ini terdiri dari data primer dan data sekunder, data primer dilakukan dengan teknik survei (pengamatan langsung) di lapangan untuk mendapatkan keterangan atau informasi secara jelas dan rinci mengenai suatu kondisi dengan panduan kuisioner/angket yang meliputi informasi tentang peternak (umur, pendidikan, pengalaman bermitra, jumlah kepemilikan ternak, jumlah kapasitas ternak, dan lain sebagainya), sedangkan data sekunder diperoleh dari Dinas Pertanian, Peternakan, pelaku kemitraan serta instansi terkait.

\section{Hasil dan Pembahasan}

Gerbang kertosusila merupakan kumpulan beberapa wilayah di propinsi Jawa Timur, yang terdiri dari : Gresik, Bangkalan, Mojokerto, Surabaya, Sidoarjo dan Lamongan. Wilayah gerbang kertosusila ini secara geografis terletak antara 111-133 BT dan 6-8 $8^{0} \mathrm{LS}$, dengan luas $5.881,05 \mathrm{~km}^{2}$. Secara administratif terdiri dari : 6 wilayah Kabupaten/Kota, 132 kecamatan dan $1.926 \mathrm{desa} /$ kelurahan.
Data demografi wilayah gerbang kertosusila ini menunjukkan bahwa sebagian besar tenaga kerja terserap di sektor pertanian dengan proporsi sebesar 40,5 persen, sementara sektor ini memiliki produktifitas tenaga kerja paling rendah dibandingkan dengan sektor ekonomi lainnya. Kondisi ini ditunjang dengan fakta bahwa sebagian besar tenaga kerja memiliki latar belakang pendidikan yang rendah (ditinjau dari tingkat pendidikan tenaga kerja adalah lulusan SMA/SMK). Data statistik mencatat bahwa pada tahun 2010, sekitar $48 \%$ tenaga kerja di wilayah gerbang kertosusila berpendidikan SMA/SMK. Rendahnya tingkat pendidikan ini menjadi salah satu penyebab rendahnya tingkat upah dan rata-rata upah bulanan.

Rendahnya tingkat upah tersebut diakui atau tidak, merupakan salah satu daya tarik untuk investasi usaha di Propinsi Jawa Timur. Khususnya usaha pada sektor pertanian, dimana usaha pada sektor ini masih didominasi dengan usaha padat karya namun rentan terhadap musim dan wabah penyakit. Pada usaha sektor ini, penyertaan tenaga kerja yang tinggi dengan upah yang minimum menjadi salah satu ciri khasnya. Termasuk didalamnya adalah sub sektor peternakan, dalam hal ini adalah usaha (ayam) broiler. Usaha broiler yang telah berkembang dengan cukup pesat sejak kurun 3 dekade yang lalu tersebut menjadikan usaha pada sub sektor ini menjadi salah satu idola masyarakat. $\mathrm{Hal}$ ter-sebut adalah kontributor terhadap pengem-bangan usaha broiler menjadi sebuah industri yang menggerakkan banyak sektor pereko-nomian didalamnya. Dinamisasi pergerakan industri ini menjadi salah satu indikator pembangunan suatu wilayah.

Wilayah gerbang kertosusila merupakan salah satu sentra peternakan broiler baik secara mandiri maupun 
kemitraan, menjadikan wilayah ini cukup dinamis dalam industri khususnya industri broiler. Dinamisasi usaha ini menunjang berkembangnya industri lain yang mendukung industri broiler di wilayah tersebut, diantaranya adalah berkembangnya pabrik pakan, pabrik pengolahan produk broiler dan usaha kemitraan budidaya broiler. Khusus pada usaha kemitraan budidaya broiler, yang selanjutnya akan disebut ke-mitraan broiler, berkembang cukup pesat di wilayah ini dengan semakin banyaknya perusahaan kemitraan broiler.

Tabel 1 tersebut menunjukkan adanya beberapa model kemitraan broiler yang digunakan oleh perusahaan di wilayah Gerbangkertosusila. Adapun beberapa model kemitraan yang ada di Gerbangkertosusila adalah:

1. Model kemitraan Kontrak

Manajemen yaitu model kerjasama kemitraan antara peternak (plasma) dengan perusahaan (inti) yang menyediakan Sapronak (Sarana Produksi Peternakan) dengan kesepakatan/kontrak perjanjian yang dibuat bersama. Plasma menyediakan fasilitas kandang, peralatan, biaya operasional dan tenaga kerja sedangkan Inti sebagai penyedia sapronak. Model kemitraan ini menguasai hampir 50\% usaha kemitraan broiler yang ada. Diantaranya Japfa Comfeed dengan PT. Ciomas Adi Satwa dan PKP, Charoen Pokhpan (NUJ), Malindo, Suja (Grup CJ), Surya Mitra Farm, Panca Patriot, Wonokoyo, Subur, DMC, Ganesa Bumi Putra dll.

2. Model kemitraan Poultry Shop, merupakan kombinasi antara pola dagang umum dan pola keagenan. Harga sapronak sudah disepakati, namun untuk harga jual broiler disesuaikan dengan kondisi pasar dan menjadi hak plasma. Plasma cukup menyediakan kandang, tenaga kerja dan pemeliharaan. Umur dan harga panen ditentukan oleh plasma sesuai dengan pasar. Bila harga pasar dibawah BEP plasma akan menanggung kerugian. Beberapa Poultry Shop (PS) yang melayani usaha kemitraan broiler seperti ini adalah Nagamas, Enggal, Tiara, Bintang Unggas, Naima Putra, Mekar, Maju Bersama, Bintang Madura, Amandari, Jaya, Brawijaya, Mahameru, Primadona, Sawahan, Simo Joyo, Ngagel dan lain-lain.

3. Model Kemitraan kontrak Tenaga Kerja/Kontrak Upah Kerja, plasma memperoleh hasil atas perhitungan biaya upah kerja per ekor DOC, dan insentif atas prestasi produksi. Plasma cukup menyediakan kandang, tenaga kerja dan pemeliharaan, plasma memperoleh upah sebagai jasa kerja/upah kerja dari inti. Perusahaan kemitraan broiler yang ada di wilayah Gerbang kertosusila dan menganut model kemitraan kontrak Tenaga Kerja yang adalah: ALKA, Reza Perkasa, Ternak Sejati Bambang HOC dll.

4. Model Kemitraan Kontrak bagi hasil, atau sama dengan model kemitraan Penyertaan Saham. Plasma memperoleh pembiayaan modal dari inti sedangkan keuntungan yang didapat dilakukan bagi hasil sesuai dengan kontrak. Plasma cukup menyediakan kandang, tenaga kerja dan pemeliharaan. Umur dan Harga panen ditentukan oleh peternak sesuai dengan pasar. Perusahaan kemitraan broiler yang ada di wilayah Gerbang kertosusila dan menganut model kemitraan Bagi Hasil adalah: Bintang Unggas, Anwar Sierad, Persada dan lain-lain 
N. Supartini, H. Darmawan dan K. Setyowati / Buana Sains Vol 17 No 1 : 9 -18

Tabel 1. Perusahaan (Inti) Kemitraan Broiler di Gerbang Kertosusila

\begin{tabular}{|c|c|c|c|c|c|}
\hline No & Kab/Kota & Kontrak Manj & Poultry Shop & $\begin{array}{c}\text { Tenaga } \\
\text { Kerja }\end{array}$ & $\begin{array}{c}\text { Bagi } \\
\text { Hasil }\end{array}$ \\
\hline 1 & Gresik & $\begin{array}{l}\text { NUJ, DMC, } \\
\text { Malindo, SMF }\end{array}$ & Enggal & $\begin{array}{l}\text { Sumber } \\
\text { Makmur, } \\
\text { ALKA }\end{array}$ & $\begin{array}{l}\text { Ciomas, } \\
\text { AS }\end{array}$ \\
\hline 2 & Bangkalan & DMC, AS & $\begin{array}{l}\text { Bintang Madura, Sinar } \\
\text { Utama, Jaya }\end{array}$ & $\begin{array}{l}\text { Sinar Utama } \\
\text { PS }\end{array}$ & Persada \\
\hline 3 & Mojokerto & $\begin{array}{l}\text { SMF, DMC, PKP, } \\
\text { Ciomas, SIP, UJM } \\
\text { dan Genesis }\end{array}$ & $\begin{array}{l}\text { Jaya PS, Brawijaya PS, } \\
\text { Sanjaya PS, Mahameru } \\
\text { PS }\end{array}$ & $\begin{array}{l}\text { Alka, Ternak } \\
\text { Sejati, } \\
\text { Bambang } \\
\text { HOC, H. } \\
\text { Zainal }\end{array}$ & $\begin{array}{l}\text { Ternak } \\
\text { Sejati, Drh. } \\
\text { Wati BF }\end{array}$ \\
\hline 4 & Surabaya & NUJ, DMC, AS & $\begin{array}{l}\text { Primadona PS, } \\
\text { Sawahan PS, jaya PS, } \\
\text { Simo Jaya PS, Ngagel } \\
\text { PS }\end{array}$ & Sejati & Ciomas \\
\hline 5 & Sidoarjo & $\begin{array}{l}\text { AS, Subur, Ciomas, } \\
\text { Malindo }\end{array}$ & $\begin{array}{l}\text { Subur Makmur PS, } \\
\text { Cendrawasih PS, } 81 \\
\text { PS, Ternak Sejahtera } \\
\text { PS }\end{array}$ & $\begin{array}{l}\text { Paul Iskandar, } \\
\text { Reza Perkasa }\end{array}$ & Wonokoyo \\
\hline 6 & Lamongan & $\begin{array}{l}\text { SML, NUJ, Ciomas, } \\
\text { Rezar Perkasa, } \\
\text { Wonokoyo, Malindo }\end{array}$ & $\begin{array}{l}\text { Tiara PS, Bintang } \\
\text { Unggas PS, Mekar PS, } \\
\text { Maju Bersama PS }\end{array}$ & $\begin{array}{l}\text { Bintang } \\
\text { Unggas, Alka, } \\
\text { Nama Putra, } \\
\text { Reza Perkasa }\end{array}$ & $\begin{array}{l}\text { Bintang } \\
\text { Unggas }\end{array}$ \\
\hline
\end{tabular}

Model kemitraan yang dipilih oleh peternak dipengaruhi pada dasar pengambilan keputusan peternak yang berbeda. Perbedaan tersebut dominan dipengaruhi oleh tingkat pendidikan peternak. Hal ini oleh Kuncoro (1997), dinyatakan bahwa pendidikan menjadikan landasan dalam mengubah tata nilai baru dan meningkatkan daya pikir menuju kearah peningkatan kesejahteraan. Perubahan tersebut berdampak pada kualitas Sumber Daya

\section{Tingkat Pendidikan Peternak}

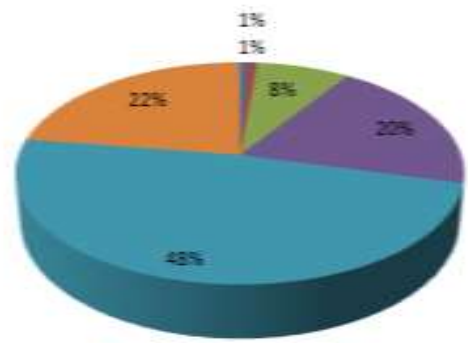

(A)
Manusia (SDM) dalam hal ini adalah peternak. Kualitas sumberdaya manusia ditentukan oleh tingkat pendidikan formal yang dimilikinya. Oleh karena itu, pengukuran tingkat pendidikan penting dilakukan yang dimaksudkan untuk mengukur kualitas sumberdaya peternak. Distribusi jumlah peternak sebagai sampel berdasarkan tingkat pendidikan formal tertera pada gambar 1.

\section{Umur Peternak}

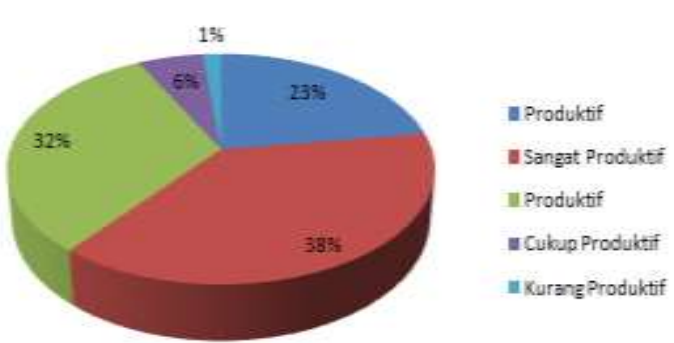

(B)

Gambar 1. (A) Profil Peternak Berdasarkan Tingkat Pendidikan Formal dan (B) Profil Peternak Berdasarkan Umur 
Gambar 1 (A) menunjukkan bahwa peternak yang berpendidikan tamat SLTA atau biasa dikenal SMA/SMK adalah yang tertinggi dengan persentase $48 \%$. Hal ini menunjukkan bahwa peternak kemitraan broiler di lokasi penelitian telah cukup mengenyam pendidikan dasar dan menengah. Kondisi ini cukup penting mengingat SDM yang dibutuhkan oleh industri broiler khususnya pada bidang kemitraan broiler adalah tenaga kerja yang terdidik, baik secara formal maupun keahliannya.

Kondisi yang mengejutkan ditunjuk-kan oleh tingkat pendidikan peternak yang tamat SLTP dan Perguruan tinggi dengan persentase yang berdekatan, yaitu $19,73 \%$ dan $22,67 \%$. Hal ini menunjukkan bahwa kesadaran masyarakat tentang pentingnya pendidikan formal telah disadari semua kalangan serta menunjukkan bahwa usaha kemitraan broiler semakin populer dikalangan masyarakat yang ber-pendidikan tinggi. Sehingga pandangan bahwa usaha peternakan, khususnya peternak kemitraan broiler adalah usaha yang kurang menarik bagi para generasi muda telah berubah.

Tinjauan pendidikan formal dan hubungannya dengan generasi muda telah menunjukkan fenomena positif. Hal ini menarik untuk ditinjau lebih lanjut tentang umur peternak. Kajian terhadap data umur peternak dimaksudkan untuk mengetahui potensi SDM yang tersedia. Umur peternak besarta anggota keluarganya secara struktur dibagi menjadi lima kelompok umur. Pada kelompok umur produktif, SDM masih mampu berfikir kedepan dengan mengadopsi inovasi baru. Dampak inovasi ini diharapkan dapat meningkatkan produktifitas usaha dan secara fisik mampu mengembangkan usahanya. Adapun distribusi jumlah dan persentase peternak berdasar umur di lokasi penelitian tertera pada gambar 1(B).

Gambar 1 (B) menunjukkan sebuah profil yang berkorelasi positif dengan tingkat pendidikan peternak. Data tersebut menunjukkan bahwa peternak kemitraan broiler di lokasi penelitian didominasi oleh kelompok yang produktif (jumlah persentase total 98,40\%), terbagi oleh kelompok produktif, sangat produktif dan cukup produktif dengan rentang umur $15-55$ tahun. Pada umur ini dianggap cukup mempunyai kemampuan untuk menjalan-kan usaha kemitraan broiler yang banyak menggunakan fisik dan pikiran.

Tabel 2 menunjukkan bahwa usaha kemitraan broiler di lokasi penelitian ini sangat didukung oleh masyarakat karena cukup mendukung ekonomi masyarakat. Peternak selalu melibatkan tenaga kerja keluarga (TKK), dalam hal ini yang menyebutkan bahwa peternak biasanya mempekerjakan seluruh keluarga serta partisipasi wanita (ibu) dan anak cukup tinggi. Seluruh peternak merasa sangat puas dengan hasil yang diperoleh, walaupun kebijakan pemerintah belum menyentuh mereka. Sebagian besar $(72,95 \%)$ peternak dalam hal pengambilan keputusan cenderung secara musyawarah.

Kondisi ini mencerminkan peternak sebagai bagian dari masyarakat desa yang menurut Ginting (1992), salah satunya mempunyai sifat paguyuban dan dapat menghidupi keperluan dan kebutuhan hidupnya sendiri.

Kondisi dukungan sosial budaya yang terbaca dari profil peternak tersebut berdampak, baik secara langsung maupun tidak langsung, 
N. Supartini, H. Darmawan dan K. Setyowati / Buana Sains Vol 17 No 1 : 9 -18

terhadap kondisi ekonomi peternak di lokasi penelitian. Salah satu indikator untuk mengukur kondisi ekonomi peternak menurut Wisadirana (2003) adalah mata pencaharian peternak. Mata pencaharian peternak penting untuk diketahui karena hal tersebut merupakan prilaku ekonomi peternak di desa dalam memenuhi kebutuhannya. Distribusi mata pencaharian peternak di lokasi penelitian ditampilkan pada tabel 3.

Tabel 2. Dukungan Sosial - Budaya di Lokasi Penelitian

\begin{tabular}{|c|c|c|c|c|}
\hline \multirow{2}{*}{ No } & \multirow{2}{*}{ Item Sosbud } & \multirow{2}{*}{ Item Jawaban } & \multicolumn{2}{|c|}{ Jumlah Peternak } \\
\hline & & & $\mathbf{N}$ & $\%$ \\
\hline 1 & $\begin{array}{l}\text { Jumlah TKK yang } \\
\text { terlibat }\end{array}$ & Seluruh Anggota & 750 & 100 \\
\hline 2 & Kepuasan Panen & Memuaskan & 750 & 100 \\
\hline 3 & Kelembagaan Sosial & $\begin{array}{l}\text { Kelompok Peternak } \\
\text { Plasma }\end{array}$ & 750 & 100 \\
\hline 4 & Pengambilan Keputusan & $\begin{array}{l}\text { a. Musyawarah } \\
\text { b. Terkadang } \\
\text { c. Sendiri }\end{array}$ & $\begin{array}{c}547 \\
55 \\
148\end{array}$ & $\begin{array}{c}72.95 \\
7.38 \\
19.67\end{array}$ \\
\hline 5 & Kebijakan Pemerintah & Tidak Ada & 750 & 100 \\
\hline
\end{tabular}

Tabel 3. Distribusi Mata Pencaharian Peternak di Lokasi Penelitian

\begin{tabular}{|c|c|c|c|}
\hline \multirow{2}{*}{ No } & \multirow{2}{*}{ Mata Pencaharian } & \multicolumn{2}{|c|}{ Jumlah dan Persentase Peternak } \\
\hline & & $\mathbf{N}$ & $\%$ \\
\hline 1 & Pekerjaan Utama : Petani & 332 & 44.26 \\
\hline 2 & Pekerjaan Utama : Peternak & 166 & 22.13 \\
\hline 3 & Pekerjaan Utama : Berdagang & 86 & 11.48 \\
\hline 4 & Pekerjaan Utama : Nelayan & 25 & 3.28 \\
\hline 5 & Pekerjaan Utama : Guru dan PNS & 141 & 18.85 \\
\hline 6 & Pekerjaan Sampingan : & & \\
\hline & Peternak & 418 & 55.74 \\
\hline & Berdagang & 252 & 33.61 \\
\hline & Buruh Bangunan & 49 & 6.56 \\
\hline & Nelayan & 31 & 4.10 \\
\hline
\end{tabular}

Tabel 3 menunjukkan bahwa peternak kemitraan broiler di lokasi penelitian tidak menjadikan usaha kemitraan broiler sebagai usaha satu-satunya dan juga tidak menjadi pekerjaan utama, dimana tercatat $22,13 \%$ peternak yang menjadikan kemitraan broiler sebagai pekerjaan utamanya dan tercatat berada pada peringkat kedua pekerjaan utama.

Pekerjaan utama yang tertinggi adalah sebagai petani $(44,26 \%)$ dengan pekerjaan sampingan tertinggi adalah sebagai peternak kemitraan broiler $(55,74 \%)$. Hal ini menunjukkan bahwa peternak masih menjadi pekerjaan sampingan dan sesuai dengan pendapat Sumarno (2000) yang menyatakan bahwa usaha peternakan sebagai bagian usaha pertanian bersifat sub-sistein, sehingga minim diversifikasi usaha dan inovasi.

Minimnya diversifikasi usaha dan inovasi tersebut berdampak kepada pola prilaku budidaya kemitraan broiler yang dijalankan berdasarkan pengalaman. Hal tersebut dilihat dari rataan waktu peternak dalam mengikuti kemitraan broiler yang cukup lama. Semakin 
tingginya pengalaman peternak kemitraan broiler dalam men-jalankan usahanya, maka semakin lama mereka mengenal, mengetahui dan dapat mengatasi permasalahan dalam kemitraan broiler sehingga hasilnya

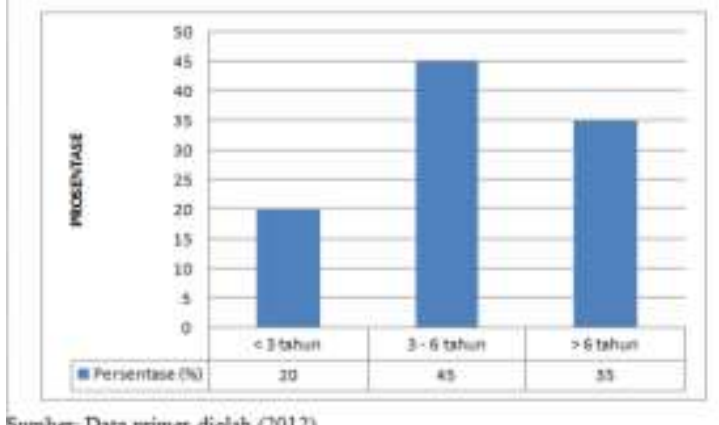

(A) maksimal dan membuat pelaku kemitraan akan mengembangkan usahannya. Deskripsi lama beternak peternak di lokasi penelitian ditampilkan pada gambar $2(\mathrm{~A})$.

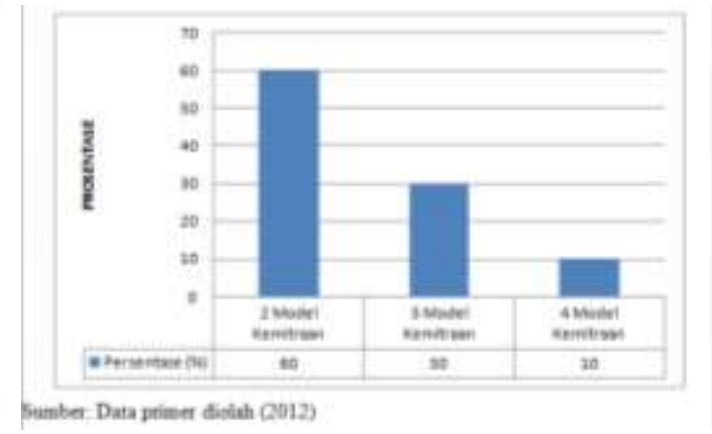

(B)

Gambar 2. (A) Profil Peternak Berdasarkan Lama Beternak dan (B) Karakteristik Responden Berdasarkan Model Kemitraan

Gambar 2 (A) menunjukkan responden yang lama beternak kurang dari tiga tahun hanya $20 \%$, responden yang sudah berternak 3-6 tahun sebesar 45\% sedangkan yang sudah berternak $>6$ tahun sebanyak 35\%. Data tersebut memberikan indikasi bahwa para pelaku kemitraan broiler sudah lama menggeluti usahanya sehingga sudah berpengalaman dalam memelihara broiler. Hal ini sesuai dengan salah satu syarat kerjasama broiler meskipun secara implisit telah ada di dalam kontrak kerjasama.

Penelitian ini responden yang di jadikan narasumber adalah responden yang pernah mengikuti model kemitraan lebih dari satu. Dengan mengikuti beberapa macam model kemitraan diharapkan responden dapat memberikan gambaran seobyektif mungkin tentang kuisioner penelitian. Untuk lebih mengetahui berapa pola yang pernah diikuti oleh responden dapat dilihat pada diagram gambar 2(B).

Gambar 2 (B) menunjukkan bahwa mayoritas responden sudah pernah mengikuti dua model kemitraan $60 \%$ sehingga responden mampu memberi gambaran yang jelas tentang usaha kemitraan broiler dari sudut pandang model kemitraan yang pernah diikutinya. Peternak di wilayah Gerbangkertosusila mempunyai alasan dan pandangan berbeda tentang model kemitraan, rata-rata pelaku kemitraan akan bertahan lama dalam model kemitraan yang dirasa aman dan menguntungkan.

Model kemitraan yang dirasa aman dan menguntungkan tersebut berdampak pada pendapatan yang diterima. Kriteria pendapatan dapat ditingkatkan melalui efisiensi manajemen. Selama ini kemitraan menggunakan tolok ukur IP dan FCR sebagai cara menghitung efisiensi performan dari peternakan broiler. IP (Indek Prestasi) merupakan penilaian berdasarkan kematian, bobot badan, umur dan FCR. FCR (Feed Convertion Ratio) adalah kg pakan yang dikonsumsi untuk menghasilkan $\mathrm{kg}$ daging. 
Hasil penelitian mendeksripsikan bahwa IP berpengaruh pada efisiensi performan broiler tetapi kurang berpengaruh terhadap pendapatan, yang disebabkan karena IP merupakan standar internasional yang menggunakan sistim perkandangan modern, sedangkan peternakan di Indonesia masih tradisional dengan kepemilikan populasi yang kecil, dan dari pihak inti terdapat keterbatasan suplay sapronak yang tidak stabil. FCR merupakan efisiensi penggunaan pakan yang berpengaruh terhadap pendapatan, yang disebabkan karena semakin kecil FCR akan semakin meningkatkan pendapatan. Dalam beberapa model kemitraan bila FCR masuk standar plasma akan memperoleh bonus tambahan.

Hasil penelitian menjelaskan bahwa faktor yang berpengaruh terhadap efisiensi manajemen dalam melakukan kemitraan Kontrak Manajemen yang paling tepat adalah : umur, jumlah pakan, bobot badan/ekor dan sebagai kontrol adalah setoran bobot broiler hidup. Umur rata-rata panen broiler di wilayah Gerbangkertosusila adalah umur 35 hari. Standar konsumsi pakan pada umur tersebut adalah 60 zak per 1000 ekor dengan bobot badan 1.7-1.8 $\mathrm{kg} /$ ekor, dan setiap satu zak pakan ratarata memperoleh $29 \mathrm{~kg}$ berat broiler hidup.

Rekapitulasi Hasil Pendapatan Plasma (RHPP) merupakan penilaian prestasi plasma pada setiap kali panen yang meliputi faktor umur, pakan, bobot badan dan setoran. Berdasarkan hal tersebut dapat dinilai melalui score yang diklasifikasikan kedalam 4 klasifikasi score, yaitu :

1. Score A, merupakan plasma yang sangat loyal dan dapat dipertahankan serta dikembangkan.
2. Score B, merupakan plasma yang loyal dan juga dapat dikembangkan.

3. Score $C$, perlu dipertahankan dengan pembinaan lebih lanjut agar menjadi plasma yang lebih baik.

4. Score D, plasma yang tidak komitmen terhadap kontrak kerjasama dan sulit untuk dibina sehingga tidak perlu dipertahankan

Peternak memiliki beberapa kriteria dalam memilih alternatif model kemitraan broiler. Untuk itu, ditetapkan 11 kriteria peternak dalam memilih alternatif model kemitraannya. Kesebelas kriteria tersebut adalah : Kriteria Lapangan kerja, Kriteria Pendapatan, Kriteria Harga Kontrak, Kriteria Mengurangi Resiko, Kriteria Akses Teknologi, Kriteria Informasi Pasar, Kriteria Akses Permodalan, Kriteria Insentif, Kriteria Informasi Pasar, Kriteria Berkesinambungan dan Kriteria Meningkatkan daya Saing. Kesebelas kriteria tersebut kemudian dianalisis dengan metode AHP (Analitical Hierarchy Process).

Berdasarkan hasil analisis kriteria terpenting menurut responden adalah pendapatan dengan bobot nilai sebesar 0,13, selanjutnya adalah kriteria mengurangi resiko dengan bobot nilai sebesar 0,12. Kriteria lapangan kerja, harga kontrak danakses permodalan mempunyai bobot nilai sama sebesar 0.11 . Kriteria informasi pasar memiliki bobot nilai sama sebesar 0,10. Kriteria akses teknologi, harga pasar dan berkesinambungan mempunyai bobot nilai sebesar 0,09 serta kriteria insentif dan meningkatkan daya saing mempunyai bobot sama sebesar 0,08 .

Lima prioritas kriteria utama yaitu: pendapatan, mengurangi resiko, lapangan kerja, harga kontrak dan akses permodalan, dengan kisaran bobot nilai 0,11 - 0,13. Kriteria pendapatan merupakan prioritas utama bagi 
peternak kemitraan broiler dalam melakukan usahanyadan hal ini sesuai dengan penelitian Priyono, dkk (2004) yang menyebutkan bahwa adanya hubungan yang signifikan antara tingkat pelaksanaan usaha kemitraan broiler dengan tingkat pendapatan peternak broiler. Setiap usaha ingin memperoleh pendapatan maksimal, semakin tinggi pendapatan akan menjadi prioritas plasma/inti untuk melakukan dan mengembangkan usahanya karena pendapatan merupakan tujuan usaha. Pendapatan yang sesuai dengan apa yang diharapkan pelaku kemitraan baik inti maupun plasma akan membuat kerjasama kemitraan menjadi nyaman, harmonis dan berkelanjutan. Sutawi (2002), menyatakan bahwa pendapatan peternak dipengaruhi oleh manajemen pemeliharaan oleh peternak itu sendiri dan mendapatkan bimbingan teknis dari inti.

\section{Kesimpulan dan Saran}

1. Pelaku kemitraan broiler berusia produktif sebesar 90\%, tingkat pendidikan SLTA ke atas sebesar $75 \%$, pekerjaan utama berprofesi sebagai wirausaha sebesar $45 \%$, lama beternak lebih dari 3 tahun sebesar $80 \%$ dan mengikuti 2 pola kemitraan sebesar $60 \%$.

2. Pendapatan merupakan kriteria yang paling dibutuhkan, terbukti nilai kriteria pendapatan memiliki bobot tertinggi sebesar 0.12 .

3. Model kemitraan Kontrak Manajemen merupakan model yang paling diminati oleh responden, karena ada 8 pilihan prioritas yaitu: kriteria lapangan kerja, kriteria harga kontrak, kriteria Mengurangi resiko, kriteria akses teknologi, kriteria akses permodalan, Kriteria Insentif, kriteria meningkatkan daya saing, kriteria berkesinambungan.
Kesimpulan diatas menjadi dasar penyusunan saran sebagai berikut :

1. Peternakan merupakan agro industri yang menjanjikan, untuk itu perlu upaya-upaya promotif sehingga menjadi salah satu terobosan di dalam meningkatkan kesejahteraan taraf hidup masyarakat

2. Model kemitraan Kontrak Manajemen merupakan model yang paling diminati oleh responden, disisi lain kriteria pendapatan merupakan kriteria yang paling dibutuhkan. Untuk itu perlu adanya perbaikan terkait dengan kriteria pendapatan yang berkeadilan dalam model kemitraan Kontrak Manajemen

\section{Daftar Pustaka}

Ginting, E. 1992. Buku Sosiologi Pedesaan. Universitas Brawijaya-LUW Animal Husbandry Project. Malang

Kuncoro, E.A. 2008. Leadership sebagai Primary Forces dalam Competitive Strength, Competitive area, Competitive Result guna meningkatkan Daya Saing Perguruan Tinggi. Bandung: Alfabeta.Mulyantono. 2003. Kemilaunya Broiler Riubnya Kemitraan. Poultry Indonesia, Edisi Januari. GAPPI

Priyono. 2004. Performa Pelaksanaan Kemitraan dalam Usaba Peternakan Ayam Ras Pedaging. Jurnal LIPI Vol. 6205111115

Sutawi, MP., 2002. Manajemen Agribisnis. Bayu Media. UMM Pres.

Sumarno 2000. Dasar Perencanaan Pengembangan Wilayah Dan Pemberdayaan Masyarakat Berbasis Pertanian : Model Dan Metode. Fakultas Pertanian Universitas Brawijaya. Malang

Wisadirana, D.,2003. Model Pengembangan Agribisnis Sapi Potong Berdasar Analisis Kelayakan Sosial Budaya Dan Ekonomi. Proseding Seminar Nasional Pengembangan Sapi Lokal. Fakultas Peternakan. Universitas Brawijaya. Malang 